\title{
Profiles in Science for Science Librarians: Paul Callistus Sereno
}

\section{Citation}

Barr, Dorothy. 2017. “Profiles in Science for Science Librarians: Paul Callistus Sereno." Science \& Technology Libraries (January 13): 1-7. doi:10.1080/0194262x.2016.1270873.

\section{Published Version}

10.1080/0194262x.2016.1270873

\section{Permanent link}

http://nrs.harvard.edu/urn-3:HUL.InstRepos:30649196

\section{Terms of Use}

This article was downloaded from Harvard University's DASH repository, and is made available under the terms and conditions applicable to Other Posted Material, as set forth at http:// nrs.harvard.edu/urn-3:HUL.InstRepos:dash.current.terms-of-use\#LAA

\section{Share Your Story}

The Harvard community has made this article openly available.

Please share how this access benefits you. Submit a story.

\section{Accessibility}




\title{
PROFILES IN SCIENCE FOR SCIENCE LIBRARIANS: \\ Paul Callistus Sereno
}

\begin{abstract}
Paul Sereno is one of the better-known paleontologists of our time. His expeditions have taken him around the world, and he has discovered new dinosaurs - and other ancient creatures - in places as far-flung as Argentina, China, and various parts of Africa. He even uncovered a large Stone Age cemetery in the Sahara. In addition to his many publications in prestigious academic journals, he was a National Geographic Explorer in Residence, has received numerous awards, and has appeared in a number of documentaries.
\end{abstract}

KEYWORDS: paleontology, biography, exploration, University of Chicago.

It's every schoolchild's dream: leading expeditions to far-flung reaches of five continents, discovering dinosaurs and other ancient creatures while excavating more than 70 tons of fossils. One almost can't help conjuring up a vision of a dashing Indiana Jones-type figure. And in the case of Paul Sereno, that image would be perfectly correct; in fact, he has sometimes been dubbed "Indiana Sereno" (Fowler 1996). Sereno himself describes the life of a paleontologist as “every bit as adventurous as a kid thinks it is" (Paul Sereno 2011).

\section{EARLY LIFE AND EDUCATION}

Paul Callistus Sereno was born October 11, 1957 in Aurora Illinois and was raised in Napierville IL. He cheerfully admits to being a poor student and also rather a mischief-maker as a child. He 
first became interested in paleontology when he came across a copy of The fossil book in the high school library; it was full of illustrations and since at the time he was interested in painting, he stole the book (he still has it). His interest was cemented later by a trip to the American Museum of Natural History in New York (Jenkins 2012) and after hearing stories about paleontological expeditions, he decided that was what he wanted to do. He realized that he could "combine art, travel, science, adventure, biology, paleontology and geology" (Fowler 2012).

Sereno did his undergraduate work at Northern Illinois University in DeKalb. Although he had become enamored of a glamorous career as a paleontologist going on adventures around the world, he retained an interest in anatomical illustration and so majored in both art and biology. He went on to get first a master's degree in vertebrate zoology and then a doctorate in geological sciences at Columbia University in 1987. He then returned to Illinois as an assistant professor of organismal biology and anatomy at the University of Chicago, where he remains today as a full professor (Paul Sereno 2016).

\section{LAUNCHING A CAREER IN PALEONTOLOGY}

Sereno's first field expedition was in 1988 to Argentina. In 1958 an expedition led by famed paleontologist Alfred Romer had made preliminary discoveries in the Ischigualasto Formation in the foothills of the Andes. However, not only did they face very difficult working conditions, but they also encountered resistance and indeed downright hostility from local inhabitants and from Argentine officials. In fact, the fossils from the 1958 expedition were impounded in Buenos Aires for two years! One of the members of the expedition, James Jensen, afterwards wrote a "non-scientific" but highly entertaining account of their trials and tribulations (Jensen 2001). 
When the fossils finally reached Harvard, their significance went unnoticed for some time (Sereno 2012).

Although Argentine paleontologists made further expeditions to the area during the 1960s, the first Argentine-American Expedition did not take place until 1988, when Sereno and several students joined other paleontologists. By then conditions in the field had improved (and today the area has become a tourist destination), and also this time they had governmental and local support. Although they did not have maps from Romer's earlier expedition, a local rancher who had assisted the Argentine paleontologists in the 1960s and his nephew acted as guides (both were named Herrera, and the early dinosaur Herrerasaurus is named after the elder Herrera, who discovered it). They discovered more fossils of Herrerasaurus that provided considerable new information. It was clear that the animal had most of the characteristics of the later dinosaurs except for some features of the hip and leg bones (Sereno 2012).

In 1991, Sereno returned to Ischigualasto on the second Argentine-American Expedition and had even greater success. Among other finds, one, Eoraptor lunensis, was a small (only about $10 \mathrm{~kg}$ and one meter long) animal that dashed about on the ground on two legs - its front legs were small. Sereno first described and named it - Eoraptor means "dawn snatcher," referring to its early appearance in the line of dinosaurs. Not only did it live almost 232 million years ago, but it also lacked the specialized features found in later dinosaurs (Sereno 2012).

Originally Sereno placed Eoraptor at the base of the theropod dinosaurs, those bipedal predatory dinosaurs of Jurassic Park fame that included Tyrannosaurus rex and also evolved into modern 
birds. However, later another nearly complete skeleton of a dinosaur from the same area and time period, Eodromaeus murphi, was discovered that was clearly a carnivore. Sereno and other paleontologists reevaluated Eoraptor and decided that on the basis of its teeth, it was omnivorous and represented an early member of a different group, the sauropodomorphs (Kaplan 2011; MartÍnez, Apaldetti, \& Abelin 2012). The Sauropodomorpha are the dinosaurs that included ponderous beasts such as Diplodocus. But the discovery of these two animals living contemporaneously in the same area emphasizes the importance of the Ischigualasto Formation as a cradle of the earliest dinosaurs (Sereno 2012).

\section{FURTHER EXPEDITIONS AND DISCOVERIES}

Over the next couple of decades Sereno and colleagues made many expeditions to various parts of the world. In the 1990s the team went to Africa where they turned up Nigersaurus, a sauropod from the early Cretaceous, and using computed tomography, photographic casting and other sophisticated techniques, created a cast of the animal's brain and established its head posture for the first time. Clearly Sereno's art training has been useful in his work (Sereno et al. 2007).

Another fantastic find was Carcharodontosaurus, This gigantic theropod (bipedal carnivorous dinosaur) was possibly larger even than T. rex and roamed Africa during the early Cretaceous (ca. 145 mya-66 mya). It had been known from isolated fragments since the 1920 s, but the material had been lost during the Second World War until Sereno unearthed a partial skull and remnants of several related dinosaurs in Niger (Brusatte and Sereno 2007). 
The same paper described Spinosaurus aegypticus, another gigantic theropod but one adorned by a large sail on its back (Sereno et al. 2007). Larger than T. rex, Spinosaurus has been described as "probably the largest predatory dinosaur of the Cretaceous period" (Gimsa, Sleigh, \& Gimsa 2016). Originally discovered in 1915 , all its fossils had been in Germany and were lost during the Second World War and since then only isolated teeth and bones had been found. In 2014 Sereno and others, in describing the partial skeleton they had found, made the case that it was semiaquatic, based on its pelvis, limbs and the placement of its nostrils; in fact, they proposed that it must have spent much of its time in the water (Ibrahim et al., 2014). But ever since its discovery there has been debate about the purpose of its sail and this continues to this day. Proposals have included storage for fat, display or thermoregulation. Ibrahim et al. (2014) favored display, but Gimsa, Sleigh \& Gimsa (2016) argue that Spinosaurus used its sail in similar ways to sailfish today. For instance, it could submerge its sail to sneak up on prey, use it as a counterbalance when swinging its head to stun prey, and even use it to herd prey underwater.

In addition to his dinosaur discoveries, Sereno and his team accidentally unearthed a Neolithic human burial site in Africa in 2000 (Skeletons of the Sahara 2015). He also worked on ancient birds. For instance, from fossils found on an expedition to China he was able to reconstruct the early bird Sinornis. He showed that it was one of the earliest birds capable of sustained flight because it had both primitive features such as those found in Archaeopteryx and also other features that are found in modern flying birds. For instance, Archaeopteryx was not a great flyer but Sinornis had a broad sternum to which flight muscles were attached and could also fold its 
wings, but later birds had large ridged sternums and tails that were modified to make them more maneuverable (Sereno \& Chenggang 1992).

Still another spectacular discovery was also not a dinosaur but it was certainly quite a find. Sarchosuchus imperator, an ancient crocodilian, was the length of a school bus, weighed as much as eight metric tons and would have dwarfed even the largest of today's crocodiles (Sereno, Larsson, Sidor, \& Gado 2001). Sereno and his group found enough remains of these socalled super-crocs (the scientific name means "emperor of flesh-eating crocodilians") that he deduced that they were ambush predators capable of devouring large prey found along the river (they have even been called "dinosaur-munching behemoths" (Perkins 2001).

Much of Sereno's work has led to greater understanding of dinosaur evolution, which has always been a big interest of his. The ancient supercontinent Gondwana joined with the supercontinent of Laurasia around 300 million years ago (mya) to form Pangaea. By about 200 mya, the joined continents had begun to separate and by the late Cretaceous the various dinosaur groups had become more and more isolated (Sereno et al. 1996). The discoveries made by Sereno and others in the mid-1990s in Africa were important in establishing the radiation of dinosaurs during this period. They discovered that two of the dinosaurs discovered in Morocco were most closely related to ones on the other landmass after the split had taken place, indicating that the animals had been still able to cross (Fowler 1996).

But the course of paleontological research does not always run smooth, especially since new findings keep changing our view of ancient creatures and landscapes. For instance, Raptorex was 
described by Sereno and colleagues in 2009 as a miniature $T$. rex look-alike that they thought lived about 125 mya, long before $T$. rex came on the scene. Although it was roughly 100 times smaller than its famous descendant, the specimen already had the tiny arms, powerful legs, large head, powerful jaws and even the strong sense of smell (as shown by the large olfactory bulb in the brain) that make T. rex so distinctive (Sereno et al. 2009). However, the early dating was questioned, and today the consensus is that the specimen was a juvenile of an early Tyrannosaurid that actually lived quite a bit later, around 70 mya (Fowler, Woodward, Freedman, Larson, \& Horner 2011). With new fossils being constantly discovered, our understanding of dinosaur evolution continues to change (Brusatte \& Carr 2016).

\section{OTHER ACHIEVEMENTS}

TaxonSearch (taxonsearch.uchicago.edu/) is a database that Sereno and colleagues created in 2005 to provide an efficient tool for taxonomists for sharing, logging and locating taxonomic information above the level of genus. An example collection of "Stem Archosauria" included 789 taxonomic records (Sereno, McAllister, \& Brusatte 2005). Although paleontologists still refer to TaxonSearch records, it does not appear to have been kept up to date as there have been so many changes in the field.

In 1996, Sereno married Gabrielle Lyon, who was on his 1995 expedition to the Sahara. In 1999 they cofounded Project Exploration, a Chicago-based project that provided out-of-school programs in science, technology, engineering and mathematics (STEM) for underrepresented young people in grades 6-12 (http://www.projectexploration.org/). The project was awarded the Presidential Award for Excellence in Science, Mathematics and Engineering Mentoring in 2009. 
Sereno has been a National Geographic Society Explorer-in-Residence and, never one to shun publicity, has been featured in many documentaries, popular books and newspaper and magazine articles. Among other awards and accolades, he was named Teacher of the Year in 1993 by the Chicago Tribune; received the University Medal for Excellence from Columbia University in 1999; and was one of People magazine's 50 Most Beautiful People in 1997.

\section{CONCLUSION}

Sereno is still on the faculty of the University of Chicago, and his many publications are listed at http://paulsereno.uchicago.edu/research/publications/. Communication with the public remains important to him (Wong 2000). With his good looks and popularity with the public, Sereno has become a highly recognizable figure. This has not always gone over well with fellow scientists, as he acknowledged in a 2000 interview with Scientific American (Wong 2000). "If there is publicity, it looks as if you seek publicity, and that seems like an unscientific thing," he also remarked (Fowler 1996).

Sereno continues to take obvious joy in his paleontological work as "adventure with a purpose. How else to describe a scientific discipline that allows you to romp in remote corners of the globe, resurrecting gargantuan creatures that have never been seen? The trick to big fossil finds? You've got to be able to go where no one has gone before-while learning to enjoy $125^{\circ} \mathrm{F}$ heat" (http://paulsereno.uchicago.edu/about/full_biography/). And he is passionate about working with young people, as shown by his involvement with Project Exploration. He especially enjoys taking students on mini fossil-finding expeditions to Montana. As he stated in that 2000 
interview, "I'm absolutely, fundamentally convinced that most of us will never understand the various talents we have because we never test ourselves enough" (Wong 2000).

\section{REFERENCES}

Brusatte, S. L., \& Carr, T. D. 2016. The phylogeny and evolutionary history of tyrannosauroid dinosaurs. Scientific Reports 6: 20252. doi:10.1038/srep20252.

Brusatte, S. L. \& Paul C. Sereno. 2007. A new species of Carcharodontosaurus (Dinodauria: Theropoda) from the Cenomanian of Niger and a revision of the genus. Journal of Vertebrate Paleontology 27 (4): 902-916. doi:ANSOCD]2.0.CO;2.

Fowler, B. 1996. Paul C. Sereno: Imp's evolution to fossil finder. In L. Chang (Ed.), Scientists at work: Profiles of today's groundbreaking scientists from Science Times, the New York Times (pp. 233-238). New York; London: McGraw-Hill.

Fowler, D. W., Woodward, H. N., Freedman, E. A., Larson, P. L., \& Horner, J. R. 2011. Reanalysis of "Raptorex kriegsteini": A juvenile tyrannosaurid dinosaur from Mongolia. PLoS One 6 (6): e21376. doi://dx.doi.org.ezpprod1.hul.harvard.edu/10.1371/journal.pone.0021376.

Gimsa, J., Sleigh, R., \& Gimsa, U. 2016. The riddle of Spinosaurus aegyptiacus' dorsal sail. Geological Magazine 153 (3), 544. doi:10.1017/S0016756815000801.

Ibrahim, N., Sereno, P. C., Dal Sasso, C., Maganuco, S., Fabbri, M., Martill, D. M., .. . Iurino, D. A. 2014. Semiaquatic adaptations in a giant predatory dinosaur. Science (New York, N.Y.), 345 (6204): 1613-6. doi:10.1126/science.1258750

Jenkins, M. C. 2012. National Geographic 125 years: Legendary photographs, adventures, and discoveries that changed the world. Washington, D.C.: National Geographic. 
Jensen, J. A. 2001. The road to Chilecito. Launceston, Tas.: Queen Victoria Museum and Art Gallery.

Kaplan, M. 2011. Move over Eoraptor. Nature News. doi:10.1038/news.2011.17

MartÍnez, R. N., Apaldetti, C., \& Abelin, D. 2012. Basal sauropodomorphs from the Ischigualasto formation. Journal of Vertebrate Paleontology 32 (Supplement 1): 51-69. doi:10.1080/02724634.2013.819361.

National Geographic Society. n.d. Paul Sereno, paleontologist: Information, facts, news, photos. Retrieved from http://www.nationalgeographic.com/explorers/bios/paul-sereno/.

Paul Sereno. 2011. Retrieved from http://www.chicagomag.com/Chicago-Magazine/March2011/50-Most-Beautiful-Chicagoans-Paul-Sereno/.

Paul Sereno paleontologist. Retrieved from http://paulsereno.uchicago.edu/about/full_biography/.

Paul Sereno: Digging up dinosaurs. 2005. [Video/DVD]

Perkins, S. 2001. Fossils indicate ... Wow, what a croc! Science News 160 (17), 260.

Sereno, P. 2012. Preface. Journal of Vertebrate Paleontology 32, Supplement to Number 6 (Memoir 12), 1-9.

Sereno, Paul. 2016. Britannnica Academica Encyclopaedia. Retrieved from http://academic.eb.com.ezp-prod1.hul.harvard.edu/levels/collegiate/article/475361.

Sereno, P. C., Brusatte, S. L., Kriegstein, H. J., Cloward, K., Lin, T., \& Xijin, Z. 2009. Tyrannosaurid skeletal design first evolved at small body size. Science 326 (5951), 418422. doi:10.1126/science.1177428.

Sereno, P. C., \& Chenggang, R. 1992. Early evolution of avian flight and perching: New evidence from the lower Cretaceous of China. Science 255 (5046), 845-848. 
Sereno, P. C., Dutheil, D. B., Iarochene, M., Larsson, H. C. E., Lyon, G. H., Magwene, P. M., . . . Wilson, J. A. 1996. Predatory dinosaurs from the Sahara and late cretaceous faunal differentiation. Science 272 (5264), 986-991.

Sereno, P. C., Larsson, H. C. E., Sidor, C. A., \& Gado, B. 2001. The giant crocodyliform Sarcosuchus from the Cretaceous of Africa. Science 294 (5546), 1516-1519.

Sereno, P. C., McAllister, S., \& Brusatte, S. L. 2005. TaxonSearch: A relational database for suprageneric taxa and phylogenetic definitions. Phyloinformatics 8, 1-21. doi:10.5281/zenodo.59797.

Sereno, P. C., Wilson, J. A., Witmer, L. M., Whitlock, J. A., Maga, A., Ide, O., \& Rowe, T. A. 2007. Structural extremes in a Cretaceous dinosaur. Plos One 2 (11), e1230. doi:10.1371/journal.pone.0001230.

Skeletons of the Sahara. 2015. Retrieved from http://www.pbs.org/program/skeletons-sahara/.

Wong, K. 2000. Paleontology's Indiana Jones. Scientific American 282 (6), 36-37. doi:10.1038/scientificamerican0600-36. 